\title{
Section XVI: Natural Environment
}

\author{
Rule 138 \\ When planning and conducting military operations during an armed con- \\ flict, due regard should be given to the natural environment.
}

\section{Commentary}

1. According to Article 55(1), $1^{\text {st }}$ sentence of AP/I, "care shall be taken in warfare to protect the natural environment against widespread, long-term and severe damage". However, several States have repeatedly declared that Article 55 does not reflect customary international law. ${ }^{1}$

2. Rule 44 of the Customary International Humanitarian Law Study (CIHL), applicable in international and arguably also in non-international armed conflicts, states that "methods and means of warfare must be employed with due regard to the protection and preservation of the natural environment". ${ }^{2}$ The Group of Experts were of the view that the practice and opinio juris provided in support of Rule 44 CIHL were insufficient to establish a mandatory requirement of customary international law and that the word "should" was more appropriate.

3. Further objections have been made to the use of the phrase "due regard". It has been argued that the due regard standard is too broad to be of a customary nature in relation to care given to the natural environment during armed conflict.

\footnotetext{
${ }^{1}$ U.S Response to ICRC CIHL Study 521 ("France and the United States repeatedly have declared that Articles 35 (3) and 55 of AP/I, from which the Study derives the first sentence of rule 45, do not reflect customary international law. In their instrument of ratification of the $1980 \mathrm{CCW}$, both France and the United States asserted that the preambular paragraph in the CCW treaty, which refers to the substance of Articles 35 (3) and 55, applied only to states that have accepted those articles.

${ }^{2}$ CIHL, see chapter "Section XI: Destruction of Property", fn. 1, Rule $44\left(1^{\text {st }}\right.$ sentence).
} 


\section{Rule 139}

Rule 138 applies to the natural environment of:

(a) The Belligerent States,

(b) Neutral States,

(c) International sea areas, and

(d) Outer Space, the Moon and other Celestial Bodies (chapter "Section I: Outer Space").

\section{Commentary}

1. Since damage to the natural environment may easily transcend borders, the scope of Rule 138 is not limited to the territory of the Belligerent States and applies to all domains of warfare.

2. Outer Space, the Moon and other Celestial Bodies are defined in Rule 1.

3. It must be noted that it is controversial whether and to what extent Outer Space, the Moon and Other Celestial Bodies are considered to be parts of the natural environment for the purposes of LOAC.

\section{Rule 140}

In international armed conflict-subject to Rules 142 and 143-States should not use means and methods of warfare which are intended or may be expected to cause widespread, long-term and severe damage to the natural environment.

\section{Commentary}

1. Under AP/I, it is prohibited for States Parties to employ methods or means of warfare that are intended, or may be expected, to cause widespread, long-term and severe damage to the natural environment (Article 35(3)). In Article 55(1) of AP/I, a similar prohibition is stipulated. The latter provision identifies "the prohibition of the use of methods or means of warfare which are intended or may be expected to cause such damage to the natural environment and thereby to prejudice the health or survival of the population" as one of the manifestations of the duty of care in warfare to protect the natural environment.

2. Although protecting the environment during an international armed conflict-and taking into consideration the possible environmental implications of an attackare incontrovertibly desirable as a matter of policy, some States have expressed the view that the AP/I prohibition does not constitute customary international law, with regard to either conventional or nuclear weapons. ${ }^{3}$ That said, it is clear under the principle of distinction that parts of the natural environment cannot be made the object of attack unless they constitute military objectives. Further criticism of

\footnotetext{
${ }^{3}$ U.S Response to ICRC CIHL Study, see fn. 1.
} 
$\mathrm{AP} / \mathrm{I}$ is that it fails to acknowledge that, after a determination of military necessity and application of the distinction principle, the use of weapons causing damage to the natural environment is prohibited when it is expected to be excessive in relation to the concrete and direct overall military advantage anticipated. ${ }^{4}$

3. The interpretation of the terms "widespread", "long-term" and "severe" (which appear both in AP/I and in the ENMOD Convention ${ }^{5}$ ) is controversial. Moreover, it is agreed that the meaning of the words in one context (AP/I) is not the same as in other contexts (in particular the ENMOD Convention).

4. Although, in the view of the ICRC, the prohibition stipulated in Article 35(3) of $\mathrm{AP} / \mathrm{I}$ is of customary nature, the assertion is not borne out by the available State practice and opinio juris. At the same time, there can hardly be any doubt that the issue of the protection of the environment in armed conflict has emerged as a particular international concern and that such a concern also manifests itself in the desirability of avoiding widespread, long-term and severe environmental damage. The practice and statements of several States, including those of States that are not Parties to AP/I, substantiate this concern.

5. Some States take the position that the application of this Rule is also subject to the principle of proportionality. These States rely, inter alia, on the terms of Article 8 (2)(b)(iv) of the Rome Statute of the International Criminal Court, 1998.

\section{Rule 141}

Under the ENMOD Convention, State Parties undertake not to engage in military or any other hostile use of environmental modification techniques having widespread, long-lasting or severe effects as the means of destruction, damage or injury to any other State Party.

\section{Commentary}

1. Under Articles 1 and 2 of the ENMOD Convention, States Parties undertake not to engage in "military or any other hostile use of environmental modification techniques [defined as any technique for changing-through the deliberate manipulation of natural processes - the dynamics, composition or structure of the Earth, including its biota, lithosphere, hydrosphere and atmosphere, or of Outer Space] having widespread, long-lasting or severe effects as the means of destruction, damage or injury to any other State Party". This means that States will refrain from using the environment itself as a weapon when fighting another State Party to the ENMOD Convention.

\footnotetext{
${ }^{4}$ Ibid

${ }^{5}$ See chapter "Section I: Outer Space”, fn. 19.
} 
2. Rule 45 of the CIHL, which stipulates a prohibition of the use of the "destruction of the natural environment [...] as a weapon", is based, inter alia, on the ENMOD Convention. However, the CIHL itself describes the customary status of the ENMOD Convention as "unclear". 6

\section{Rule 142}

Intentional destruction of any part of the natural environment qualifying as a civilian object is prohibited, unless required by imperative military necessity.

\section{Commentary}

1. Destruction of property when required by imperative military necessity is dealt with in general in chapter "Section XI: Destruction of Property" with accompanying Commentary.

2. The present Rule reflects the widely accepted view that the prohibition against the destruction or seizure of enemy property, unless required by military necessity, can be extended to apply to those parts of the natural environment that constitute civilian objects.

3. It must be borne in mind that the prohibition of the intentional destruction of the natural environment is contingent on consideration of military necessity. Absent military necessity, such destruction cannot be justified.

4. On the other hand, it has been argued that no sufficient State practice or opinio juris in support of this position (which extends the customary prohibition against destruction of enemy property as set out in chapter "Section XI: Destruction of Property") exists.

5. Although the wording of the present Rule 142 is broad, it is agreed that de minimis damage, such as the destruction of a single tree, does not constitute a violation of this Rule. It is unclear at what point destruction is no longer considered de minimis and comes within the application of the Rule as stated.

\section{Rule 143}

Although parts of the natural environment constitute civilian objects other parts may be regarded as military objectives by location, purpose or use (e.g., camouflage).

\section{Commentary}

1. Many portions of the natural environment may be viewed presumptively as civilian objects. Still, there are two schools of thought in this matter. One school of thought regards the natural environment as worthy of protection per se. Another school of thought, anthropocentric in nature, focuses on those portions

\footnotetext{
${ }^{6}$ CIHL, see chapter “Section XI: Destruction of Property”, fn. 1, vol. I, page 155.
} 
of the natural environment that human beings are dependent on for their survival or health.

2. However extensively the inherently protected portions of the natural environment are viewed, it cannot be denied that-due to purpose, location or use-parts of the environment can qualify as military objectives. This is expressly recognized in Protocol III of the CCW Convention, which lays down in Article 2(4): "It is prohibited to make forests or other kinds of plant cover the object of attack by incendiary weapons except when such natural elements are used to cover, conceal or camouflage combatants or other military objectives, or are themselves military objectives".

\section{Rule 144}

Feasible precautions should be taken to avoid, or in any event to minimize, incidental damage to parts of the natural environment constituting civilian objects.

\section{Commentary}

1. The general principle for States Parties to AP/I, as stated in Article 57(1), is that parties to an armed conflict must take constant care to spare civilian objects. This principle extends to the natural environment, if and when it constitutes a civilian object.

2. Constant care includes the notion of taking feasible precautions in attack to avoid or minimize incidental damage to those parts of the environment that constitute civilian objects.

\section{Rule 145}

It is prohibited to launch an attack against a lawful target, which may be expected to cause incidental damage to those parts of the natural environment that constitute civilian objects, expected to be excessive in relation to the concrete and direct overall military advantage anticipated.

\section{Commentary}

1. This Rule expresses the principle of proportionality, which is commented upon in general terms in paragraph 1 of the Commentary to Rule 11. Several States, including some not party to AP/I, have accepted the obligation to include expected environmental damage in the proportionality assessment of a proposed attack. In a similar vein, the ICJ had earlier observed that "States must take environmental considerations into account when assessing what is necessary and proportionate in the pursuit of legitimate military objectives. Respect for the 
environment is one of the elements that go to assessing whether an action is in conformity with the principles of necessity and proportionality."7

2. However, the Rule applies only to parts of the natural environment constituting civilian objects. For example, where the natural environment is used for camouflage or as a shield for armed forces (see Rule 143), that part of the natural environment may be considered a military objective by use or location. With regard to destruction of parts of the natural environment as a consequence of movement of military forces, see chapter "Section XI: Destruction of Property" with Commentary.

Open Access This chapter is licensed under the terms of the Creative Commons Attribution 4.0 International License (http://creativecommons.org/licenses/by/4.0/), which permits use, sharing, adaptation, distribution and reproduction in any medium or format, as long as you give appropriate credit to the original author(s) and the source, provide a link to the Creative Commons licence and indicate if changes were made.

The images or other third party material in this chapter are included in the chapter's Creative Commons licence, unless indicated otherwise in a credit line to the material. If material is not included in the chapter's Creative Commons licence and your intended use is not permitted by statutory regulation or exceeds the permitted use, you will need to obtain permission directly from the copyright holder.

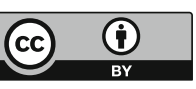

${ }^{7}$ ICJ Advisory Opinions in the Nuclear Weapons Case, see chapter "Outer Space", fn. 8, para 30. 